\title{
Allergy profile study in patients attending a private allergy clinic
}

\author{
Iris R. Baratawidjaja*, Pramita P. Baratawidjaja ${ }^{\dagger}$, Allan Darwis $^{\dagger}$, Karnen G. Baratawidjaja* $^{*}$
}

\begin{abstract}
Abstrak
Studi dilakukan pada 1000 pasien yang berkunjung ke klinik swasta di Jakarta, terdiri atas 416 pria dan 584 wanita dengan usia antara 1 bulan - 79 tahun. Tujuan studi ialah untukmengetahui gambaran yang luas mengenai berbagai reaksi alergi dan hubungannya pada berbagai golongan usia. Pasien dibagi dalam golongan usia A (0-5 thn), B (6-13 thn), C (14-30thn), D (31-50thn) dan E (51-78thn). Prevalensi asma tertinggi ditemukan pada A dan rinitis pada $B$ yang disertai dengan sensitivitas tertinggi terhadap tungau debu rumah. Di kedua golongan usia ini asma dan rinitis ditemukan lebih banyak pada anak laki dibanding perempuan. Urticaria merupakan alergi tersering dan ditemukan terbanyak pada wanita usia muda. Alergi kontak terbanyak ditemukan terhadap nickel dan fragrance, lebih banyak pada wanita dibanding pria meskipun perbedaannya tidak bermakna. Alergi obat ditemukan pada 25,6\%, tersering terhadap analgesik dan NSAID, penisilin, sulfa dan tetracyclin. Alergi makanan ditemukan pada 28,0\% pasien, tersering terhadap ikan, udang/kepiting, telor dan kacang tanah. Studi menemukan prevalensi alergi yang sangat tinggi terhadap berbagai alergen pada golongan usia tertentu, yang nampaknya berhubungan dengan faktor dalam lingkungan. Penulis menganjurkan untukmemberikan lebih banyak perhatian terhadap penanganan dan pencegahan penyakit alergi pada anak dan wanita muda.
\end{abstract}

\begin{abstract}
A study was conducted on 1000 patients attending a private allergy clinic in Jakarta, consisting of 416 males and 584 females, age between 1 month and 79 years. The aim of the study was to assemble a more comprehensive picture of the relationship between allergic reactions and allergy-related diseases across all age groups. The patients were grouped into $A(0-5 y r), B(6-13 y r), C(14-30 y r)$, $D(31-50 y r)$ and $E$ (51-79yr). The highest prevalence of both asthma and rhinitis were found in group $B$ which were accompanied with the highest sensitivity to housedust mite. More males were affected compared to females. Urticaria was the most common allergy with highest prevalence in young adult females. Most common contact allergy were due to nickel and fragrance which affected more females compared to males. Drug allergy was found in $25.6 \%$, mostly due to analgesic and NSAID, penicillin, sulfa and tetracyclin. Food allergy was found in $28.0 \%$, mostly due to fish, crustacean, egg and peanut. The study found abnormally high prevalence of allergy to several allergens in specific age groups, all seemingly related to environmental causes. The authors recommend more attention should be paid to the management and prevention of allergic diseases in the younger age group and young adult females.
\end{abstract}

Keywords: Allergy profile, risk factor, sensitisation, better management, early prevention

Incidence statistics of allergic diseases for Indonesia are difficult to obtain because of limited facilities, time and funding available to researchers. A few studies using questionnaires have found a $5 \%-6.5 \%$ prevalence of asthma and $9.8 \%-27.0 \%$ of rhinitis in children and adults respectively. ${ }^{1}$

Our hospital offers several alternatives for an allergy sufferer. The Emergency Unit and the Departments of Child Health, ENT, Dermatology and Medicine all have allergy treatment capabilities. Asthmatic patients

\footnotetext{
"Division of Allergy-Immunology, Department of Medicine,

Faculty of Medicine, University of Indonesia, Jakarta

${ }^{\dagger}$ Allergy and Immunology Clinic, Jakarta
}

may also be treated at the Division of Pulmonology in the Child Health or the Department of Pulmonology. Unfortunately, doctors working in one clinic may not see the entire range of allergic diseases and therefore will not be able to effectively compare profiles of different allergic diseases in different age groups. In addition, the lack of standardisation between studies increases the difficulty of producing meaningful comparisons. Comparing data from within studies is much more reliable. In our study we had the opportunity to observe prevalence, sex distribution, atopic and other influences of various allergic diseases in all age groups. We hope these results will make a useful contribution to the existing data for Indonesia, even more to better management and prevention of allergic diseases in general. 


\section{METHODS}

In this study, we drew 1000 files from the nearly 5000 case histories of patients treated since 1992-1997 at the Allergy-Immunology Clinic. Most patients were referred by outside general practitioners or specialists (internists, paediatricians, dermatologists, ENT specialists and others) with diagnoses such as allergic rhinitis (further called rhinitis), dermatitis, bronchial asthma, drug /food allergy and chronic urticaria for allergy evaluation, or with symptoms of possible allergic mechanisms.

The patients were classified into group A $(0-5 \mathrm{yr})$, B (6-13 yr), C (14-30 yr), D (31-50 yr) and E (51-79) yr. Every patient was given a general physical examination supplemented by Skin Prick Test (SPT), Patch Test and specific IgE (ELISA) measurement, chest X-ray (on all patients with asthma and chronic cough) and sinus X-ray when indicated. A further diagnosis of bronchial asthma was made with a spirometric examination, PFR measurement (Wright PFM and Mini Wright PFM) before and after inhalation, or recorded twice a day for at least 14 days.

Skin tests performed for various extracts of allergens such as food, molds, pollen, cat, dog, House Dust Mite (Dermatophagoides pteronyssinus and Dermatophagoides farinae), cockroach and latex. The European Standard for Contact Dermatitis Allergens were used in the PatchTest. Specific IgE measurement was done on patients with skin abnormality, patients taking antihistamines, dermographism or those with other allergic disorders to obtain for comprehensive results.

The results were analysed by descriptive statistic method. Analysis for comparing subgroup proportion by Chi Square Test and $p$ value 0.05 was indicative of a significant difference. All statistical analysis was performed using Epi Info version 6.03 (CDC Atlanta 1996).

\section{RESULTS AND DISCUSSION}

The 1000 patients aged between 1 month - 79 years were comprised of 416 males (mean $29.4 \mathrm{yr}, \mathrm{SD} \pm 15.3$ ) and 584 females (mean $27.3 \mathrm{yr}, \mathrm{SD} \pm 12.5$ ). Because prevalence, sex distribution, triggers and other factors may vary in different age groups, subjects were divided into five age groups. The total number of patients of each age group is shown on table 1 .

\section{PREVALENCE AND SEX DISTRIBUTION}

The prevalence of the allergic diseases in 1000 patients ranked by frequency were $451(45.1 \%)$ urticaria, 390 (39.0\%) rhinitis, $288(28.8 \%)$ bronchial asthma, 280 (28.0\%) food allergy, 256 (25.6\%) drug allergy, 87 (8.7\%) chronic cough, 77 (7.7\%) Quincke's edema and $75(7.5 \%)$ dermatitis (table 1). In this study chronic cough is included, as increased incidence of chronic cough often precedes asthma. Prevalence comparisons for the allergic diseases by age group are shown in figure 1.

We studied the sex distribution of the allergic diseases in different age groups ( table 2). Except in group C (female $=2.7 \times$ males), the ratio male/female patients were relatively constant. The sex distribution and the possible factors contributing to female overrepresentation in group $\mathrm{C}$ will be discussed below.

\section{a. Bronchial asthma}

The prevalence of bronchial asthma in group A (figure 2) was $39.8 \%$ increasing in group $B$ reaching to a maximum at $42.0 \%$, decreasing in groups $C$ and $D$ and increasing slightly in group $\mathrm{E}$. The rise in prevalence in group B can be explained due to the high activity levels of older age group exposing them to more indoor and outdoor allergens. ${ }^{2}$

In Group A (table 2), the prevalence of asthma was greater for males compared to females $(p=0.021)$, agreeing with the literatures. ${ }^{3,4}$ The disparity is reduced in older age groups. As remissions from asthma during adolescence are less likely in females, the ratio of male/female asthmatics reaches approximate parity in adulthood. ${ }^{5} \mathrm{We}$ found $114(39.6 \%)$ rhinitis among 288 asthmatics accompanied with rhinitis, as compared with approximately $5-20 \%$ of the general population. Among 390 patients with rhinitis, we further found $180(46.2 \%)$ asthmatics as compared with $5 \%$ prevalence noted in the general population. This finding showed a strong link between bronchial asthma and rhinitis which is in agreement with other finding. The mechanisms connecting upper and lower airway dysfunction are not entirely understood. ${ }^{6}$

\section{b. Chronic cough}

We did not find any sign of tuberculous process or other significant abnormality but an increased marking on chest X-ray of all patients with chronic cough. The higher prevalence of chronic cough in group A (20.4\%) and $\mathrm{E}(13.7 \%)$ compared to other groups, is probably due to virus infections common in group $\mathrm{A}$, while in 
Table 1. Prevalence of Different Allergic Diseases in Different Age Groups

\begin{tabular}{|c|c|c|c|c|c|c|c|c|c|c|c|c|c|c|c|c|}
\hline \multirow[b]{2}{*}{ A: $0-5 y r$} & \multicolumn{2}{|c|}{$\begin{array}{l}\text { Bronchial } \\
\text { Asthma }\end{array}$} & \multicolumn{2}{|c|}{ Chronic cough } & \multicolumn{2}{|c|}{ Rhinitis } & \multicolumn{2}{|c|}{$\begin{array}{l}\text { Quincke's } \\
\text { Edema }\end{array}$} & \multicolumn{2}{|c|}{ Urticaria } & \multicolumn{2}{|c|}{ Dermatitis } & \multicolumn{2}{|c|}{ Drug Allergy } & \multicolumn{2}{|c|}{ Food Allergy } \\
\hline & 37 & $39.78 \%$ & 19 & $20.43 \%$ & 37 & $39.78 \%$ & 6 & $6.45 \%$ & 29 & $31.18 \%$ & 8 & $8.60 \%$ & 16 & $17.20 \%$ & 22 & $23.66 \%$ \\
\hline B: $6-13 y r$ & 60 & $41.96 \%$ & 13 & $9.09 \%$ & 73 & $51.05 \%$ & 12 & $8.39 \%$ & 53 & $37.06 \%$ & 7 & $4.90 \%$ & 26 & $18.18 \%$ & 29 & $20.28 \%$ \\
\hline C: $14-\mathbf{3 0} \mathrm{yr}$ & 96 & $27.67 \%$ & 17 & $4.90 \%$ & 157 & $45.24 \%$ & 24 & $6.92 \%$ & 156 & $44.96 \%$ & 20 & $5.76 \%$ & 75 & $21.61 \%$ & 108 & $31.12 \%$ \\
\hline $\mathrm{D}: 31-50 \mathrm{yr}$ & 67 & $20.81 \%$ & 26 & $8.07 \%$ & 103 & $31.99 \%$ & 27 & $8.39 \%$ & 168 & $52.17 \%$ & 29 & $9.01 \%$ & 104 & $32.30 \%$ & 96 & $29.81 \%$ \\
\hline E: $51-79 \mathrm{yr}$ & 28 & $29.47 \%$ & 13 & $13.68 \%$ & 20 & $21.05 \%$ & 8 & $8.42 \%$ & 45 & $47.37 \%$ & 11 & $11.58 \%$ & 35 & $36.84 \%$ & 25 & $26.32 \%$ \\
\hline & 288 & $28.80 \%$ & 88 & $8.80 \%$ & 390 & $39.00 \%$ & $\pi$ & $7.70 \%$ & 451 & $45.10 \%$ & 75 & $7.50 \%$ & 256 & $25.60 \%$ & 280 & $28.00 \%$ \\
\hline
\end{tabular}

Table 2. Sex Distribution and HDM Sensitivity in Different Allergic Diseases

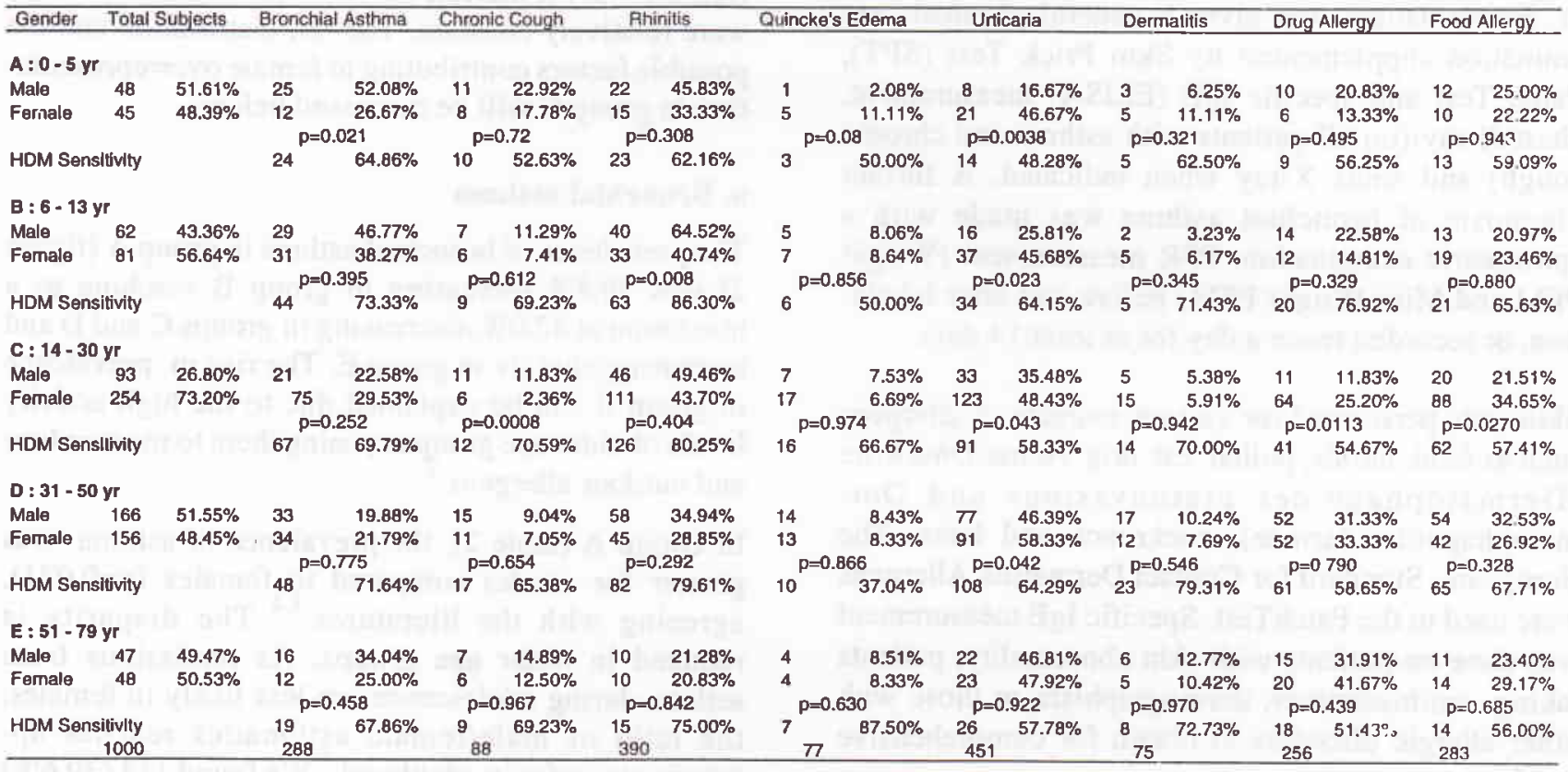




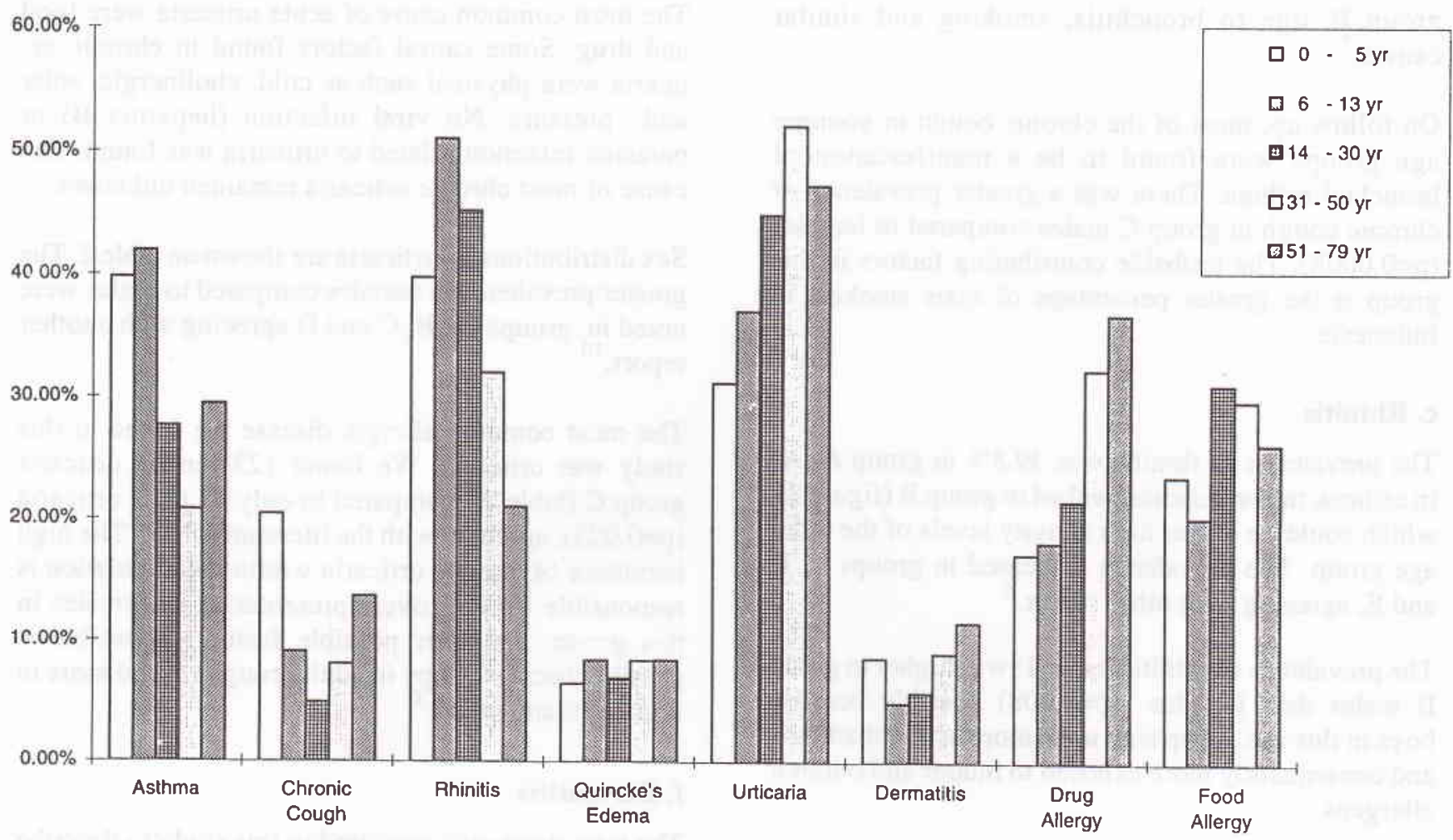

Figure 1. Prevalence of different allergic diseases in different age groups

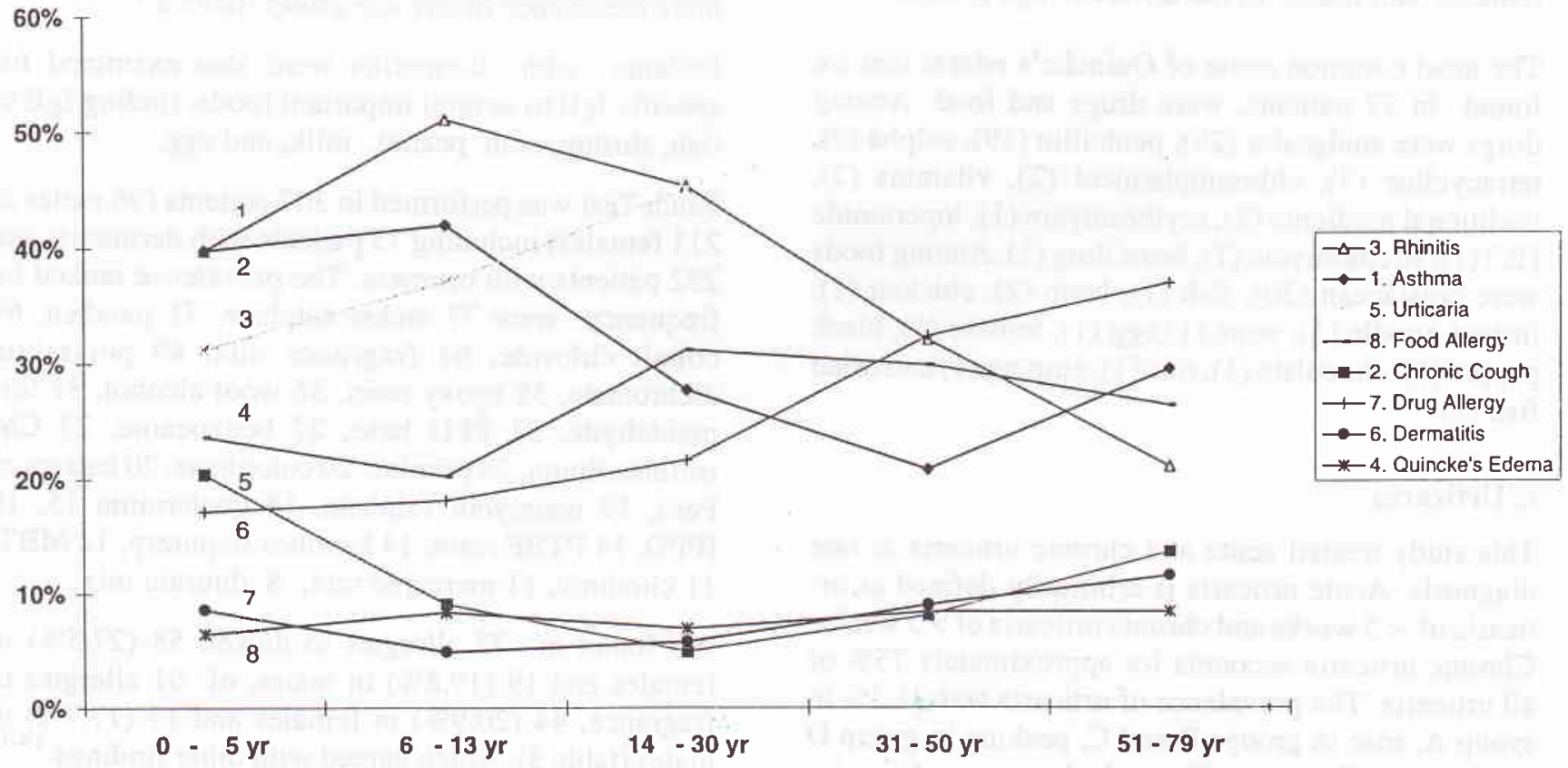

Figure 2. Prevalence of allergic diseases in different age groups 


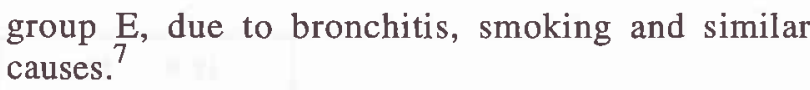

On follow up, most of the chronic cough in younger age groups were found to be a manifestation of bronchial asthma. There was a greater prevalence of chronic cough in group $\mathrm{C}$ males compared to females ( $p=0.0008$ ). The probable contributing factors in this group is the greater percentage of male smokers in Indonesia.

\section{c. Rhinitis}

The prevalence of rhinitis was $39.8 \%$ in group A. As in asthma, the prevalence peaked in group B (figure 2), which could be due to high activity levels of the older age group. The prevalence decreased in groups C, D and $\mathrm{E}$, agreeing with other report. ${ }^{8}$

The prevalence of rhinitis (table 1) was higher in group $B$ males than females $(\mathrm{p}=0.008)$ possibly because boys in this age group tend to be more active than girls and consequently more exposed to indoor and outdoor allergens.

\section{d. Quincke's edema}

The prevalence of Quincke's edema was between $6.5 \%$ and $8.4 \%$, similar in all age groups. In many patients Quincke's edema occurred with urticaria. No difference was found in the prevalence between females and males in the different age groups.

The most common cause of Quincke's edema that we found in 77 patients, were drugs and food. Among drugs were analgesics (29), penicillin (19), sulpha (9), tetracycline (3), chloramphenicol (2), vitamins (2), traditional medicine (2), erythromycin (1), loperamide $\mathrm{HCl}(1)$, streptomycin (1), heart drug (1). Among foods were crustacean (30), fish (7), lamb (2), chicken (1), instant noodle (1), wine (1),egg (1), tomato (1), black pepper (1), chocolate (1), rice (1), emping (1) and dried fish (1).

\section{e. Urticaria}

This study treated acute and chronic urticaria as one diagnosis. Acute urticaria is arbitrarily defined as urticaria of $<5$ weeks and chronic urticaria of $>5$ weeks. Chronic urticaria accounts for approximately $75 \%$ of all urticaria. The prevalence of urticaria was $31.2 \%$ in group A, rose in groups B and C, peaking in group D (table 1 and figure 1). Group E, however, showed a lower prevalence than group D agreeing with other report. ${ }^{9}$
The most common cause of acute urticaria were food and drug. Some causal factors found in chronic urticaria were physical such as cold, cholinergic, solar and pressure. No viral infection (hepatitis B) or parasitic infection related to urticaria was found. The cause of most chronic urticaria remained unknown.

Sex distributions in urticaria are shown on table 2. The greater prevalence in females compared to males were noted in groups A, B, C and D agreeing with another report. $^{10}$

The most common allergic disease we found in this study was urticaria. We found 123 female urticaria group $\mathrm{C}$ (table 2 ) compared to only 33 male urticaria $(\mathrm{p}=0.023)$, agreeing with the literatures. ${ }^{11-12}$ The high incidence of female urticaria within the population is responsible for the overrepresentation of females in this group. An other possible factor responsible is possibly because atopy in adult group is found more in females than males. ${ }^{13}$

\section{f. Dermatitis}

The term dermatitis was used in this study to describe all forms of disease which involve the eczematous process, not differentiating between atopic and contact dermatitis. Dermatitis was found in 75 patients and the prevalence between the different age groups were between $4.9 \%$ and $11.6 \%$ (table 1 ). No statistically significant difference was found between female and male prevalence in any age group (table 2 ).

Patients with dermatitis were also examined for specific IgE to several important foods, finding $\operatorname{IgE}$ to fish, shrimp, crab, peanut, milk, and egg.

Patch Test was performed in 307 patients (96 males \& 211 females) including 75 patients with dermatitis and 232 patients with urticaria. The prevalence ranked by frequency were 77 nickel sulphate, 71 paraben, 69 cobalt chloride, 61 fragrance mix, 49 potassium dichromate, 38 epoxy resin, 36 wool alcohol, 31 formaldehyde, 31 PPD base, 27 benzocaine, $23 \mathrm{CM}$ isothiazolinon, 23 primine, 20 colophane, 20 balsam of Peru, 19 neomycin sulphate, 18 quaternium 15,16 IPPD, 14 PTBF resin, 14 lactones sequiterp, 12 MBT, 11 clioqinol, 11 mercapto mix, 8 thiuram mix.

We found of 77 allergies to nickel, $58(27.5 \%)$ in females and $19(19.8 \%)$ in males, of 61 allergies to fragrance, $44(20.9 \%)$ in females and $17(17.7 \%)$ in males (table 3), which agreed with other findings. ${ }^{14-16}$ However the differences between male and female were not significant $(p=0.194$ and $p=0.627$ ). The high 
incidence of these allergies in females was due to the greater likelihood of females wearing casual jewellery and using cosmetic/fragrances compared to males.

Table 3. Sex distribution in Nickel and fragrance allergy

\begin{tabular}{ccccc}
\hline Contact Allergen & Patch Test & Male & Female & Total \\
\hline Nickel & + & 19 & 58 & 77 \\
& & $19.79 \%$ & $27.49 \%$ & \\
& & 77 & 153 & 230 \\
& & $80.21 \%$ & $72.51 \%$ & $\mathrm{p}=0,194$ \\
Fragrance & & 96 & 211 & 307 \\
& & & & \\
& & $17.71 \%$ & $20.85 \%$ & 61 \\
& - & 79 & 167 & 246 \\
& & $82.29 \%$ & $79.15 \%$ & $\mathrm{p}=0,627$ \\
& Total & 96 & 211 & 307 \\
\hline
\end{tabular}

\section{g. Drug allergy}

Drug allergy was found in $256(25.6 \%)$ of 1000 patients (figure 1$)$. The prevalence in females $(\mathrm{p}<0.05)$ was higher compared to males in group C (14-30 yr.). This also can be explained by the greater allergy prevalence in females of this age group. ${ }^{13}$ The drugs most commonly causing allergic reactions ranked by frequency were: 158 analgesic and NSAID, 108 penicillin, 42 sulfa, 13 tetracycline, 8 cough remedies, 7 vitamin, 5 chloramphenicol, 4 streptomycin, 4 traditional medicine, 3 antihistamine, 2 steroid, 2 antacid and other drugs such as acyclovir, terbutaline sulfate, ephedrine, metronidazole, loparamide $\mathrm{HCl}$, rifampicin and quinolon. This list largely agrees with the literature. ${ }^{16}$

The most common clinical manifestations of drug allergy were urticaria and or Quincke's edema. Sulfa is one of the very allergenic drugs. We noted only 42 sulfa allergy cases. This is not surprising since this drug is now much less prescribed compared to the past. We also found cross reactions among the penicillin preparations and among analgesic and NSAID. Greater prevalence of drug allergy was found in females than males. This is maybe because females are more allergic in nature than males ${ }^{12}$ or because our subject consisted of more female than male patients.

\section{h. Food allergy}

We used the term food allergy in this study although food intolerance might be more appropriate, since the involvement of the immune system such as positive SPT and RAST to certain food could not always be shown. Food allergy were found in 280 (28.0\%) of 1000 patients (table 1 ). The prevalence in female was higher $(\mathrm{p}=0.02)$ compared to males in group $\mathrm{C}(14-30$ yr. group). This may be related to the greater allergy prevalence in females of this age group. The most common foods causing allergic reactions ranked by frequency were: 163 fish, 110 crustacean, $32 \mathrm{egg}, 23$ peanut, 18 chicken, 11 lamb, 7 milk, 5 durian, 5 squid, 5 food additives, 4 mussels, 4 ice, 3 pineapple, 3 green pepper, 3 rambutan, 3 dried sea fish and others (fermented cassava, MSG, corn, avocado, banana, black pepper, cheese, chocolate, emping (fried rice cracker), grape, jackfruit, soursop, tomato, tempe (fermented soybean), tuna, honey, tomato sauce, and wine. This list largely agrees with the literature. ${ }^{17-18}$ Allergy to dried fish was found much less than allergy to fresh fish. This might be due to a change in the fish allergen structure by the process of drying. We also found greater prevalence in females compared to males, due to the fact that females are more allergic than males. ${ }^{12}$

\section{SPECIAL CONSIDERATIONS}

\section{a. Sensitivity to House Dust Mite (HDM)}

Sensitivity to HDM surveyed by SPT (reaction $>2+$ ) and or specific IgE measurement to Dermatophagoides pteronyssinus were done in all patients. The significance of HDM sensitivity in asthma and rhinitis is already known. In our study, the highest HDM sensitivity in asthma (73.3\%) and rhinitis $(83.6 \%)$ were found in group $\mathrm{B}$, which also had the highest prevalence of those diseases. Many studies have found a correlation between the degree of exposure to HDM and severity of the disease. A high percentage of positive SPT reaction $(>2+)$ to HDM was also found in our patients with chronic cough $(52.6 \%-70.6 \%)$ and dermatitis $(62.5 \%-79.3 \%)$. This might be due not only to the facts that many of the patients with chronic cough and dermatitis also suffered from asthma and or rhinitis, but also that the HDM also play a role in the mechanism of these allergies. As is already mentioned, chronic cough were in many of our patients proofed to be a manifestation of bronchial asthma. Aggravation of skin symptoms after exposure to dust and improvement of eczema in patients allergic to dust while in an allergen free environment, association of elevated serum IgE in many patients with atopic dermatitis, positive Patch testing to HDM in atopic patients, have been reported. ${ }^{19}$ Epidemiological studies have also found strong evidence of a possible pathogenic link between atopic dermatitis (AD) and asthma. In par- 
ticular, young children who develop AD in the first 1-2 yr of life stand a high risk of also developing asthma before the age of 5 years. ${ }^{20,21}$ These studies suggested a pathogenic role for HDM sensitivity in atopic dermatitis which support our finding.

\section{b. Onset of asthma and sensitivity to HDM}

The onset of atopic or extrinsic asthma is reported to be more frequent in patients $<30$ year of age (early onset), while intrinsic asthma on patients $>30$ year of age (late onset). In adults who had been diagnosed as having asthma, infection with rhinovirus was usually associated with wheezy bronchitis. In our study, among the 184 early onset asthmatics, sensitivity to HDM was found in $136(73.9 \%)$ and in 94 late onset in $66(70.2 \%)$ patients. We did not find any difference in HDM sensitivity between early and late onset of asthmatics $(\mathrm{p}=0.65)$.

\section{c. Correlation between positive SPT and positive specific IgE}

\section{i. HDM}

In 297 asthmatics and allergic rhinitis patients both SPT and specific IgE to HDM measurement were performed. Of these, $292(98.3 \%)$ were positive and $5(1.7 \%)$ were negative on SPT to HDM (table 4). A further $247(83.2 \%)$ were IgE positive while 50 $(16.8 \%)$ were IgE negative to HDM. This indicated that SPT was more sensitive compared to IgE measurement $(\mathrm{p}<0.001)$.

\section{ii. Cat and Dog}

SPT and specific IgE measurements to cat allergen were performed in 35 asthmatics and/or rhinitis patients with a cat in their homes (table 4). We found $7(20.0 \%)$ were SPT positive and 12 (34.3\%) were IgE positive to cat allergen $(\mathrm{p}=0.28)$. The same procedure was performed on 40 patients for sensitivity to dog allergen with a dog in their homes. We found 10 (25.0\%) were SPT positive and $27(67.5 \%)$ were $\operatorname{IgE}$ positive to dog allergen $(\mathrm{p}<0.001)$. The tests indicated that at least $34.3 \%$ patients with a cat and at least $67.5 \%$ patients with a dog in their homes were sensitised to those pets. In contrast with sensitivity to HDM, sensitivity to dogs can be more readily discovered through IgE measurement compared to SPT. This can be explained due to the antigens used in the IgE assay. HDM antigen consists of 10 groups and usually only group 1 or group 2 is used in IgE assay. Both cat and dog allergens consist of only 2 groups of allergens and both are readily used in the assay.
Table 4. Correlation between SPT and IgE to HDM, cat and dog allergen

\begin{tabular}{lcrrrrr}
\hline \multicolumn{2}{c}{ Allergen } & \multicolumn{3}{c}{ SPT } & \multicolumn{3}{l}{ IgE } & \\
\hline HDM & + & 292 & $98.32 \%$ & 247 & $83.16 \%$ & \\
& - & 5 & $1.68 \%$ & 50 & $16.84 \%$ & $\mathrm{p}<0,001$ \\
& Total & 297 & & 297 & & \\
& & & & & & \\
Cat & + & 7 & $20.00 \%$ & 12 & $34.29 \%$ & \\
& - & 28 & $80.00 \%$ & 23 & $65.71 \%$ & $\mathrm{p}=0,28$ \\
& Total & 35 & & 35 & & \\
& & & & & & \\
Dog & + & 10 & $25.00 \%$ & 27 & $67.50 \%$ & \\
& - & 30 & $75.00 \%$ & 13 & $32.50 \%$ & $\mathrm{p}<0,001$ \\
& Total & 40 & 40 & & \\
\hline
\end{tabular}

d. SPT to cat and dog allergen in patients (asthma and rhinitis) without a cat or a dog in their homes.

We compared the positive SPT to cat and dog among patients (asthma and rhinitis) without those pets in their homes ( table 5 ). Of 265 patients without a cat in their homes, we found positive SPT in $99(37.4 \%)$ and in $166(62.6 \%)$ negative SPT to cat $(\mathrm{p}=0,07)$. Of 227 patients without dog in their homes, we found positive SPT in $72(31.7 \%)$ and in $155(68.3 \%)$ negative SPT to $\operatorname{dog}(p=0.15)$. Sensitisation to HDM occurred in the homes due to close contact with HDM allergens in mattress, pillow, sofa and carpets which are dust reservoir and places of mite infestation. Due to their aerodynamis size of $<5 \mu \mathrm{m}$, cat and dog allergens are airborne and readily inhaled by patients when visiting a home with those pets. This explains why sensitisation to cat or dog occurred also outside the homes and which are probably responsible for immediate symptoms experienced by cat and dog sensitive asthmatics following short exposure in the homes with cat or dog.

Table 5. SPT to cat and dog allergens in patients (asthma and Rhinitis) with and without cat and dog in their homes

\begin{tabular}{|c|c|c|c|c|}
\hline \multicolumn{2}{|c|}{ Pet at home } & \multirow{2}{*}{$\begin{array}{l}\text { SPT + } \\
720.00 \%\end{array}$} & \multirow{2}{*}{$\begin{array}{c}\text { SPT - } \\
2880.00 \%\end{array}$} & \multirow{2}{*}{$\frac{\text { Total }}{35}$} \\
\hline Cat & Yes & & & \\
\hline & No & 99. $37.36 \%$ & $16662.64 \%$ & $265 \mathrm{p}=0,07$ \\
\hline & Total & 106 & 194 & 300 \\
\hline \multirow[t]{3}{*}{ Dog } & Yes & $1025.00 \%$ & $3075.00 \%$ & 40 \\
\hline & No & $7231.72 \%$ & $15568.28 \%$ & $227 \mathrm{p}=0,15$ \\
\hline & Total & 82 & 185 & 267 \\
\hline
\end{tabular}




\section{e. Allergy Triad}

Allergy triad ( asthma, rhinitis and dermatitis simultaneously in one patient) was found in 6 patients ( 3 males and 3 females), 2 from group A, 3 from group C ( 1 male, 2 females) and 1 from group E. All 6 patients showed a strong sensitivity to HDM. One had a drug allergy (analgesic), one had food allergy (shrimp), and one had food (shrimp, fish, local food tempe) and drug allergy (penicillin).

\section{CONCLUSION AND RECOMMENDATION}

The most common allergic reactions found in this study ranked by frequency were urticaria $(45.1 \%)$, rhinitis $(39.0 \%)$, bronchial asthma $(28.8 \%)$, food allergy $(28.0 \%)$, drug allergy (25.6\%), Quincke's edema $(7.7 \%)$ and dermatitis $(7.5 \%)$. There are more males than females with early childhood asthma and rhinitis compared to later childhood but in adults there were more females than males with urticaria, food allergy and drug allergy. We also found a link between rhinitis and asthma.

The highest HDM sensitivity was found in the age group of 6-13 accompanied by the highest prevalence of asthma and rhinitis. High percentage of positive reaction $(>2+)$ to HDM was found also in patients with chronic cough and dermatitis. The SPT to HDM was more sensitive compared to IgE measurement. Sensitisation to cat and dog allergen also occurred outside the homes.

Ranked by frequency we found contact allergy to nickel, paraben, cobalt chloride, fragrance mix and potassium dichromate; drug allergy to analgesic, NSAID, penicillin, sulpha and food allergy to fish, crustacean, egg and peanut.

From the results of this study, we recommend house dust avoidance not only in the management of asthma and rhinitis, but also in chronic cough and dermatitis.

HDM-SPT should be carried out in the diagnosis of allergy before the measurement of specific IgE. The last assay should only be done with indications. The cat and dog allergic patients should take precaution when visiting a home with a cat or dog. Further more attention should be paid in the management and early prevention of allergy in the younger age group and young adult females.

\section{REFERENCES}

1. Baratawidjaja K, Sundaru H, Samsuridjal D, Sukmana N. Allergic disease in Indonesia. ACI News. 1992; 4:166-70.
2. Warner JO, Jackson WF. Asthma and other allergic disorders of the lung. In: Paediatric allergy. London: Wolfe; 1994. p. 17-32.

3. Thomson NC, Kirkwood EM, Lever RS. Asthma. In : Handbook of clinical allergy. Oxford: Blackwell; 1990. p. 72-124.

4. Sears MR. Epidemiology of asthma. In: O'Byrne PM (ed). Asthma as an inflammatory disease. New York: Marcel Dekker, Inc; 1990. p. 15-48.

5. Cerio R. Eczema/Dermatitis. In: Jackson WF (ed). Allergic disorders. London: Mosby-Wolfe; 1997. p. 109-26.

6. Corren J. Allergic rhinitis and asthma. How important is the link? J Allergy Clin Immunol, 1997;99:5781-6.

7. Aberg N, Sundell J, Eriksson B, Hesselmar B, Aberg A. Prevalence of allergic diseases in school children in relation to family history, upper respiratory infections and residential characteristics. Allergy 1996;51:232-7.

8. Mygind N, Dahl R. Allergic Rhinitis. In : Jackson WF, Editor. Allergic Disorders. London: Mosby-Wolfe; 1997. p. 1-18.

9. De Monchy JGR, Kauffman H. Urticaria en angio-oedeem. in allergologie. Utrecht: Wetenschappelijke uitgeverij Bunge; 1994. p. 259-67.

10. Baratawidjaja K, Soebaryo RW. A Randomised doubleblind parallel study of cetirizine versus loratadin in chronic idiopathic urticaria. Presented at the Taiwan dermatology annual congress; 8 November 1995 ; and at The $2^{\text {nd }}$ AsiaPacific congress of allergology and clinical immunology; 21 November 1995; Taipei, Taiwan.

11. Thomson NC, Kirkwood EM, Lever RS. Urticaria. In : Handbook of clinical allergy. Oxford: Blackwell; 1990. p. 220-34

12. Jackson WF. Urticaria and related allergic skin disorders. In : Allergic disorders. London: Mosby-Wolf;1997. p. 127-42.

13. Baldacci S, Modena P, Carrozzi L. Skin prick test reactivity to common aeroallergens in relation to total $\mathrm{IgE}$, respiratory symptoms, and smoking in a general population sample of northern Italy. Allergy 1996;51:149-56.

14. Holgate ST, Church MK. Eczema and contact dermatitis. pathophysiology. In: Allergy. London: Gower; 1993. p. 23.1-10

15. Fitzpatrick TB, Johnson RA, Wolff K, Polano MK, Suurmond D. Eczemaous dermatitis. In Color atlas and synopsis of clinical dermatology. NY: McGraw-Hill; 1997. p: 48-53.

16. Schultz ND, Giannini AV, Chang TT, Wong DC. Food allergy. In: The best guide to allergy. $3^{\text {rd }}$ ed. Totowa: Humana Press; 1994. p. 111-35.

17. Pascual C, Crespo JF, Sanchez-Pastor $S$ et al. The Importance of fish in IgE-mediated food hypersensitivity. ACI News 1995; (7) : 73-5.

18. Schultz ND, Giannini AV, Chang TT, Wong DC. Drug allergies. In: The best guide to allergy. $3^{\text {rd }}$ ed. Totowa: Humana Press; 1994. p. 163-78.

19. Jones SM, Sampson A. The role of allergens in atopic dermatitis. In: Gershwin ME, Leung DYM, Editors. Clinical reviews in allergy. Totowa: Humana Press; 1993. p. 471-90.

20. Warner JO. The ETAC trial: aims and methodology. Abstract for the symposium: Allergy from skin to lung. Congress of the European Respiratoy Society; 17/9/1995; p. 18 .

21. Gergen PJ, Weiss KB. Epidemiology of asthma. In: Busse WW, Holgate ST, Editors. Asthma and rhinitis. London: Blackwell;1995. p. 15. 